



\section{Fosfaatvormen in compost en andere organische meststoffen}

Inge Regelink en René Rietra

Dit onderzoek is uitgevoerd door Wageningen Environmental Research in opdracht van en gefinancierd door de branchevereniging organische reststoffen (BVOR) en vereniging afvalbedrijven (VA).

Wageningen Environmental Research

Wageningen, februari 2021

Gereviewd door:

Lotte Veenemans (onderzoeker Wageningen Environmental Research)

Akkoord voor publicatie:

Gert Jan Reinds (Team Duurzaam bodemgebruik)

Rapport 3067

ISSN 1566-7197 
Regelink, I.C., Rietra, R.P.J.J., 2021. Fosfaatvormen in compost en andere organische meststoffen. Wageningen, Wageningen Environmental Research, Rapport 3067. 26 blz.; 6 fig.; 4 tab.; 6 ref.

Compost en andere organische meststoffen bevatten fosfaat waardoor de aanvoer hiervan moet voldoen aan de fosfaatgebruiksnormen voor landbouwgrond. Voor compost geldt dat fosfaat voor $50 \%$ (tot $3,5 \mathrm{~kg} \mathrm{P}_{2} \mathrm{O}_{5} / \mathrm{kg}$ droge stof) is vrijgesteld van deze fosfaatgebruiksnorm, omdat compost voor een aanzienlijk deel bestaat uit grond dat met tuinafval wordt meegevoerd. In dit project zijn composten en andere organische meststoffen uitvoerig geanalyseerd om verschillende fosfaatvormen in kaart te brengen en dit te relateren aan de potentiële beschikbaarheid van fosfaat voor gewasopname.

Compost and other organic fertilizers contain phosphorus and their application rates should therefore comply with the $\mathrm{P}$ application rate standards for agricultural soil. Phosphorus in compost is exempted from this regulation for $50 \%$ (with a maximum of $3.5 \mathrm{~kg} \mathrm{P}_{2} \mathrm{O}_{5} / \mathrm{kg}$ dry matter) due to the fact that compost consist partly of soil originating from garden waste. This project assessed phosphorus speciation in composts and several other organic fertilisers and relates the results to the potential availability of phosphorus for crop uptake.

Trefwoorden: compost, fosfaat, organische meststoffen

Dit rapport is gratis te downloaden van https://doi.org/10.18174/541822 of op www.wur.nl/environmental-research (ga naar 'Wageningen Environmental Research' in de grijze balk onderaan). Wageningen Environmental Research verstrekt geen gedrukte exemplaren van rapporten.

2021 Wageningen Environmental Research (instituut binnen de rechtspersoon Stichting Wageningen Research), Postbus 47, 6700 AA Wageningen, T 0317480700 , www.wur.nl/environmental-research. Wageningen Environmental Research is onderdeel van Wageningen University \& Research.

- Overname, verveelvoudiging of openbaarmaking van deze uitgave is toegestaan mits met duidelijke bronvermelding.

- Overname, verveelvoudiging of openbaarmaking is niet toegestaan voor commerciële doeleinden en/of geldelijk gewin.

- Overname, verveelvoudiging of openbaarmaking is niet toegestaan voor die gedeelten van deze uitgave waarvan duidelijk is dat de auteursrechten liggen bij derden en/of zijn voorbehouden.

Wageningen Environmental Research aanvaardt geen aansprakelijkheid voor eventuele schade voortvloeiend uit het gebruik van de resultaten van dit onderzoek of de toepassing van de adviezen.

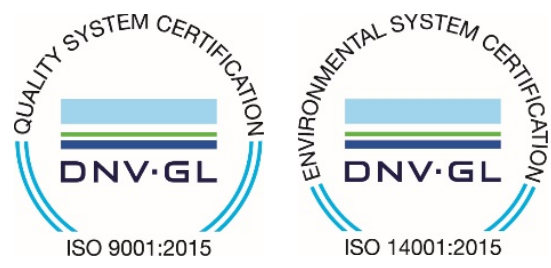

Wageningen Environmental Research werkt sinds 2003 met een ISO 9001 gecertificeerd kwaliteitsmanagementsysteem. In 2006 heeft Wageningen Environmental Research een milieuzorgsysteem geïmplementeerd, gecertificeerd volgens de norm ISO 14001.

Wageningen Environmental Research geeft via ISO 26000 invulling aan haar maatschappelijke verantwoordelijkheid.

Wageningen Environmental Research Rapport 3067 | ISSN 1566-7197

Foto omslag: Compost op kopakker; foto aangeleverd door de BVOR 


\section{Inhoud}

Verantwoording $\quad 5$

$\begin{array}{ll}\text { Samenvatting } & 7\end{array}$

1

$\begin{array}{lr}\text { Inleiding } & 9\end{array}$

2

$\begin{array}{lr}\text { Materiaal en Methoden } & 10\end{array}$

2.1 Monsters 10

$\begin{array}{ll}2.2 \text { Methoden } & 10\end{array}$

3

$\begin{array}{ll}\text { Resultaten } & 12\end{array}$

3.1 Samenstelling producten $\quad 12$

3.2 Fosfaatvormen en indicatoren voor fosfaatbeschikbaarheid 14

3.2.1 P-AL-getal 14

3.2.2 Organisch versus anorganisch fosfaat 14

$\begin{array}{ll}3.2 .3 & \text { IJzer-gebonden fosfaat }\end{array}$

3.2.4 Makkelijk beschikbare fosfaatfracties 16

3.3 Fosfaatindicatoren in compost versus organischestofgehalte $\quad 18$

4

Synthese

20

5

Conclusie

23

Literatuur 



\section{Verantwoording}

Rapport: 3067

Projectnummer: 5200045847

Wageningen Environmental Research (WENR) hecht grote waarde aan de kwaliteit van zijn eindproducten. Een review van de rapporten op wetenschappelijke kwaliteit door een referent maakt standaard onderdeel uit van ons kwaliteitsbeleid.

Akkoord Referent die het rapport heeft beoordeeld,

functie: onderzoeker Wageningen Environmental Research

naam: Lotte Veenemans

datum: $\quad 18-02-2021$

Akkoord teamleider voor de inhoud,

naam: Gert Jan Reinds

datum: $\quad 18-02-2021$ 


\section{Samenvatting}

Het gebruik van compost en organische meststoffen past binnen een kringlooplandbouw en draagt bij aan het in stand houden van organische stof (OS) gehalten van de bodem. De aanvoer van OS wordt echter beperkt door de fosfaatgebruiksnormen waardoor er vraag is naar bodemverbeteraars met een hoog aandeel effectieve organische stof (EOS) per kilogram fosfaat. Fosfaat in compost is tot $50 \%$ vrijgesteld van de fosfaatgebruiksnorm, omdat compost voor een aanzienlijk deel uit grond bestaat en een deel van het aanwezige fosfaat onderdeel is van de grondfractie. Het aandeel grondgebonden fosfaat draagt niet bij aan het verhogen van de fosfaattoestand van de ontvangende bodem en heeft zodoende geen bemestend effect anders dan bij aanvoer van grond. Compost en meststoffen worden echter doorgaans alleen geanalyseerd op het totale fosfaatgehalte, waardoor kennis over het voorkomen van verschillende fosfaatvormen in organische meststoffen en de relaties tot gewasbeschikbaarheid en fosfaatuitspoeling beperkt is. Deze studie had als doel om fosfaatvormen in compost en andere organische meststoffen vast te stellen en op basis daarvan te beoordelen of compost (groencompost en gft-compost) onderscheidend is van andere organische meststoffen, dierlijke mest en zeefgrond. ${ }^{1}$

In deze verkennende studie werden veertien producten uitvoerig gekarakteriseerd op fosfaatvormen waarbij gebruik werd gemaakt van (aangepaste) grondanalysemethoden voor analyse op (i) organisch versus anorganisch fosfaat, (ii) fosfaat gebonden aan ijzer- en aluminiumoxiden, (iii) het P-AL-getal ${ }^{2}$ en (iv) makkelijk beschikbaar fosfaat bepaald in $\mathrm{CaCl}_{2}$-extracties bij een $\mathrm{pH}$ van 5,5. Bij deze $\mathrm{pH}$ waarde gaan makkelijk oplosbare fosfaatmineralen (calciumfosfaat, struviet) in oplossing, terwijl de binding van fosfaat aan ijzerhydroxiden in stand blijft.

Zeefgronden kenmerken zich door een lage beschikbaarheid van fosfaat (0,8-6\% van totaalfosfaat) en P-AL-getallen overeenkomstig met waarden die gevonden worden in vruchtbare landbouwgronden. Groencompost is op basis van de fosfaatfracties niet duidelijk te onderscheiden van zeefgrond. Gftcompost neemt een middenpositie in tussen grond en mest met 18 tot $22 \%$ van alle fosfaat in makkelijk beschikbare vorm en daarnaast 30-50\% als ijzer-gebonden fosfaat. In digestaat van reststromen uit de suikerbietenindustrie is eveneens een aanzienlijk deel van fosfaat gebonden aan ijzeroxiden waardoor fosfaat een lage beschikbaarheid kent. In dit digestaat zijn de verhoogde ijzergehaltes te relateren aan het gebruik van ijzerwater in het vergistingsproces als middel om emissies van waterstofsulfide te beheersen. In de dikke fractie van vergiste runder- en varkensdrijfmest is nauwelijks ijzer aanwezig om fosfaat te binden en is 45 tot $87 \%$ van het totale fosfaatgehalte makkelijk beschikbaar. Het overige deel is aanwezig in de vorm van organisch fosfaat en/of slecht oplosbare fosfaatmineralen en is niet verder gespecificeerd.

Door het vaststellen van fosfaatvormen is aangetoond dat fosfaat in compost deels gebonden is aan de grondfractie en dit rechtvaardigt de $50 \%$-vrijstelling voor fosfaat in het kader van de fosfaatgebruiksnormen. Voor groencompost is een hogere vrijstelling te rechtvaardigen. Groencompost en gft-compost zijn op basis van het aandeel ijzer-gebonden fosfaat te onderscheiden van andere organische meststoffen en dit ijzer is gerelateerd aan de aanwezigheid van grond. Een uitzondering hierop is compost van gft-afval, wat verwerkt wordt door vergisting gevolgd door compostering, omdat tijdens de vergisting vaak ijzerzouten worden gedoseerd ter beheersing van waterstofsulfide-emissies. Het doseren van ijzer leidt tot een verhoogd ijzergehalte en een afname van de fractie direct beschikbaar fosfaat ten opzichte van gft-compost, waar geen ijzerzouten aan zijn toegediend. Voor gft-afval wat verwerkt wordt door vergisting en compostering is het ijzergehalte daarmee geen geschikte indicator voor het aandeel het grond.

\footnotetext{
1 Zeefgrond is de uit groenafval gezeefde groenfractie die direct, dus zonder compostering, wordt toegepast op landbouwgronden en ressorteert onder het Besluit Bodemkwaliteit.

2 Het P-AL-getal wordt gebruikt voor de afleiding van de fosfaattoestand van landbouwgronden.
} 


\section{$1 \quad$ Inleiding}

Het gebruik van compost en organische meststoffen past binnen de kringlooplandbouw waarin reststromen worden verwerkt tot nuttige meststoffen. Compost en organische meststoffen dragen bij aan de aanvoer van organische stof en nutriënten, waaronder fosfaat en stikstof. Fosfaat is echter een beperkende factor wanneer de landbouwer compost of organische meststoffen wil inzetten voor de aanvoer van organische stof. De aanvoer van fosfaat naar landbouwgrond wordt beperkt door het stelsel van de fosfaatgebruiksnormen. De hoogte van de fosfaatgebruiksnormen is gedifferentieerd naar de fosfaattoestand van de bodem. Bij een neutrale fosfaattoestand van de bodem (Pw-getal 36-45) mag op bouwland $70 \mathrm{~kg} \mathrm{P}_{2} \mathrm{O}_{5} /$ ha worden aangevoerd, wat gelijk is aan de gemiddelde fosfaatopname door het gewas. Bij een hoge fosfaattoestand ( $\mathrm{Pw}$-getal>55) is de fosfaatgebruiksruimte $\left(40 \mathrm{~kg} \mathrm{P}_{2} \mathrm{O}_{5} / \mathrm{ha}\right)$ lager dan de gewasopname en daarom wordt gestreefd naar een verlaging van de fosfaattoestand. Bij gebruik van dierlijke mest of overige organische meststoffen telt het volledige fosfaatgehalte van de meststof mee voor de fosfaatgebruiksnorm. Compost vormt een uitzondering op deze regel, omdat fosfaat in compost voor $50 \%{ }^{3}$ is vrijgesteld van de fosfaatgebruiksnorm. De onderbouwing voor deze fosfaatvrije voet is gebaseerd op het principe van de basisvracht (Ehlert, 2005): het fosfaat behorende bij de grond in compost. Compost bevat een aanzienlijke hoeveelheid grond door de inname van groen- en tuinafval. Bij gebruik van compost wordt grond met het daarin aanwezige fosfaat gerecirculeerd en daarbij neemt de totale fosfaatvoorraad in de Nederlandse bodem niet toe. Omdat grond geen meststof is, is de fractie grond in compostproducten vrijgesteld van de fosfaatgebruiksnorm. De hoogte van de vrijstelling is destijds gebaseerd op het aandeel grond in compost en het fosfaatgehalte in landbouwgrond. Ook producenten van andere organische meststoffen trachten aanspraak te maken op een vergelijkbare uitzonderingspositie. Zodoende is er vanuit de Branche Vereniging Organische Reststoffen (BVOR) en Vereniging Afvalbedrijven (VA) behoefte aan kennis over de fosfaatvormen in compost versus andere organische meststoffen en dierlijke mest. Deze inzichten kunnen mogelijk leiden tot een verdere onderbouwing van de uitzonderingspositie van compost en tevens inzicht geven in de mate waarin de fosfaatbeschikbaarheid van compost afwijkt van andere organische meststoffen en dierlijke mest.

Voor het onderzoek zijn composten, zeefgronden en diverse andere organische meststoffen bemonsterd en geanalyseerd op een aantal fosfaatindicatoren. Op basis van de analyses is de verdeling van fosfaat over verschillende fosfaatvormen afgeleid.

\footnotetext{
3 De 50\%-vrijstelling voor fosfaat in compost geldt tot een fosfaatgehalte van $7 \mathrm{~g} \mathrm{P}_{2} \mathrm{O}_{5} / \mathrm{kg}$ droge stof. Er kan dus maximaal $3.5 \mathrm{~g} \mathrm{P}_{2} \mathrm{O}_{5} / \mathrm{kg}$ droge stof worden vrijgesteld.
} 


\section{Materiaal en Methoden}

\section{$2.1 \quad$ Monsters}

Tabel 1 geeft een overzicht van de herkomst van de monsters. Per locatie is minimaal $10 \mathrm{~kg}$ materiaal bemonsterd. Hieruit is een homogeen submonster genomen, wat bewaard is in de koelcel tot analyse.

Tabel 1 Overzicht van de gebruikte zeefgronden, composten en andere organische meststoffen. ${ }^{1}$



1 Alle monsters zijn aangeleverd in februari en maart 2020.

\subsection{Methoden}

Een beknopt overzicht van de methoden is gegeven in Tabel 2. De standaardeenheid waarin fosfaat wordt uitgedrukt, verschilt tussen analyses. In deze studie is zo veel mogelijk aangesloten bij de eenheden zoals deze gebruikt worden in de landbouwpraktijk.

Totaalfosfaat wordt in organische meststoffen normaliter uitgedrukt in $\mathrm{g} \mathrm{P}_{2} \mathrm{O}_{5} / \mathrm{kg}$ product, terwijl het voor grondanalyses gebruikelijk is om gehalten uit te drukken per kg droge stof. In deze studie zijn gehalten per $\mathrm{kg}$ droge stof weergegeven, omdat daarmee de verschillen tussen de meststoffen beter geduid kunnen worden. In de landbouwpraktijk wordt fosfaat uitgedrukt in $\mathrm{P}_{2} \mathrm{O}_{5}$ en berekend als $\mathrm{P}$ maal 2.29. Het $\mathrm{P}_{\mathrm{ox}}$-gehalte wordt standaard uitgedrukt in $\mathrm{mmol} / \mathrm{kg}$ droge stof om vergelijking met het $\mathrm{Fe}_{\mathrm{ox}}$ en $\mathrm{Al}_{\mathrm{ox}}$ in $\mathrm{mmol} / \mathrm{kg}$ mogelijk te maken. $1 \mathrm{mmol} \mathrm{P}$ staat gelijk aan $31 \mathrm{mg} \mathrm{P}$ en $71 \mathrm{mg} \mathrm{P}_{2} \mathrm{O}_{5}$. 
Tabel 2 Overzicht methoden bepaling fosfaatindicatoren en bijbehorende eenheid zoals gebruikt wordt in de landbouwpraktijk.

\begin{tabular}{|c|c|c|c|}
\hline Parameter & Eenheid & Methode & Lab \\
\hline Totaalfosfaat & (g $\mathrm{P}_{2} \mathrm{O}_{5} / \mathrm{kg}$ d.s.) & Totaalfosfaat na destructie. & $\begin{array}{l}\text { LUFA Nord-West, } \\
\text { Oldenburg }\end{array}$ \\
\hline $\begin{array}{l}\text { Pox en } \\
\text { P-verzadigings- } \\
\text { graad }\end{array}$ & $\begin{array}{l}\text { (mmol/kg d.s.) en } \\
(\mathrm{mol} / \mathrm{mol})\end{array}$ & $\begin{array}{l}\mathrm{P}_{\mathrm{ox}} \text { is een maat voor de hoeveelheid fosfaat gebonden } \\
\text { aan ijzer- en aluminiumoxiden, maar extraheert } \\
\text { daarnaast ook makkelijk oplosbare fosfaatprecipitaten. } \\
\text { Extractie met ammoniumoxalaat-oxaalzuur wordt } \\
\text { gevolgd door analyse van } \mathrm{P}, \mathrm{Fe} \text { en } \mathrm{Al} \text { (ICP-OES) in het } \\
\text { filtraat. De } \mathrm{P}, \text { Fe en Al gemeten in dit extract worden } \\
\mathrm{P}_{\mathrm{ox}}, \mathrm{Fe}_{\mathrm{ox}} \text { en } \mathrm{Al}_{\mathrm{ox}} \text { genoemd. De P-verzadigingsgraad wordt } \\
\text { berekend als } \mathrm{P}_{\mathrm{ox}} /\left(0.5^{*} \mathrm{Fe}_{\mathrm{ox}}+\mathrm{Al}_{\mathrm{ox}}\right) \text {, uitgedrukt in mol/mol. }\end{array}$ & $\begin{array}{l}\text { Eurofins Agro, } \\
\text { Wageningen }\end{array}$ \\
\hline P-AL & $\left(\mathrm{mg} \mathrm{P}_{2} \mathrm{O}_{5} / 100 \mathrm{~g}\right)$ & $\begin{array}{l}\text { Extractie met een zure oplossing van ammoniumlactaat- } \\
\text { azijnzuur bij } \mathrm{pH} 3,75 \text { en analyse van } \mathrm{P}^{-} \mathrm{PO}_{4} \\
\text { (colorimetrisch). }\end{array}$ & $\begin{array}{l}\text { Eurofins Agro, } \\
\text { Wageningen }\end{array}$ \\
\hline $\mathrm{P}-\mathrm{CaCl}_{2}$ & (mg P/kg) & $\begin{array}{l}\text { Extractie met } 10 \mathrm{mM} \mathrm{CaCl} \text { bij een schudverhouding } \\
\text { afgestemd op het P-totaal ( } 150 \mathrm{mg} \mathrm{P} / \mathrm{L} \text { ) op vers } \\
\text { materiaal, gevolgd door schudden ( } 30 \mathrm{~min} \text { ), } \\
\text { centrifugeren, filtreren en analyse van het filtraat op P- } \\
\mathrm{PO}_{4} \text { (colorimetrisch). Deze methode wijkt af van de } \\
\text { standaard } \mathrm{P}-\mathrm{CaCl}_{2}-\text { methode voor grondmonsters (zie } \\
\text { tekst). }\end{array}$ & CBLB, Wageningen \\
\hline P-CAT & (mg P/L compost) & $\begin{array}{l}\text { Extractie van } 37,5 \mathrm{~g} \text { vers materiaal met } 300 \mathrm{~mL} 10 \mathrm{mM} \\
\mathrm{CaCl}_{2}+2 \mathrm{mmol} \text { DTPA en analyse van P-PO} 4 \\
\text { (colorimetrisch) en P-totaal (ICP-OES). Resultaten } \\
\text { worden uitgedrukt per L compost (o.b.v. dichtheid van } \\
\text { de compost). Dit is een standaardmethode voor } \\
\text { composten in Duitsland. }\end{array}$ & $\begin{array}{l}\text { LUFA Nord-West, } \\
\text { Oldenburg }\end{array}$ \\
\hline
\end{tabular}




\subsection{Samenstelling producten}

Figuur 1 toont het OS-gehalte, het fosfaatgehalte en de EOS/ $\mathrm{P}_{2} \mathrm{O}_{5}$-ratio van de zeefgronden, composten en andere organische meststoffen. De volledige karakterisering van alle producten is opgenomen in Tabel 3.

Het gehalte aan fosfaat per $\mathrm{kg}$ droge stof neemt toe in de volgorde zeefgrond/groencompost, digestaatkoek suikerindustrie, champost, gft-compost en dierlijke mest. Het aantal monsters per productgroep is echter beperkt, waardoor deze informatie niet gebruikt kan worden om algemene verschillen in samenstelling tussen productgroepen aan te duiden. Het OS-gehalte per $\mathrm{kg}$ droge stof varieert van gemiddeld $16 \%$ in de zeefgronden tot $>75 \%$ in de dikke fracties uit co-vergiste mest. Groencompost heeft gemiddeld een lager OS-gehalte ( $27 \%$ van d.s.) ten opzichte van gft-compost ( $46 \%$ van d.s.) Alle composten voldoen aan het criterium voor het minimale organischestofgehalte van $10 \%$ zoals vastgesteld in de Uitvoeringsregeling Meststoffenwet. Ten tijde van de afleiding van de basisvracht voor compost - en de daaruit gevolgde $50 \%$-vrijstelling voor fosfaat onder het stelsel van fosfaatgebruiksnormen - gold een criterium van $>20 \%$ OS voor composten (Ehlert, 2005). Dit geeft aan dat nu ook composten met $>10 \%$ OS en dus een hogere grondfractie als compost vermarkt kunnen worden, zonder dat de hoogte van de vrijstelling voor fosfaat daarvoor is aangepast.

Naast het OS-gehalte wordt in de praktijk gekeken naar het gehalte aan effectieve organische stof (EOS), gedefinieerd als de OS, die een jaar na toepassing nog aanwezig is in de bodem. De EOSwaarden zijn berekend op basis van humificatie-coëfficiënten zoals bepaald door Rietra et al. (niet gepubliceerd) en op basis van incubatie-experimenten. De humificatie-coëfficiënt van compost is hoger dan die van digestaten en meststoffen. Omdat het gebruik van organische meststoffen beperkt wordt door de fosfaatgebruiksnormen is het gebruikelijk om organische meststoffen te waarderen op basis van de ratio tussen EOS en fosfaat (Figuur 1). Groencompost heeft de hoogste EOS $/ \mathrm{P}_{2} \mathrm{O}_{5}$ ratio, gevolgd door gft-compost. Bij de gft-compost van installaties zonder ijzerdosering is het $\mathrm{P}_{2} \mathrm{O}_{5}$ gehalte hoger dan $7 \mathrm{~g} / \mathrm{kg}$ en bedraagt de fosfaatvrije voet $3,5 \mathrm{~g} / \mathrm{kg}$. Bij gebruik van champost, digestaatkoek en dikke fracties uit co-vergiste mest wordt per kg forfaitair fosfaat minder OS aangevoerd dan bij gebruik van gft-compost en dit verschil komt deels voort uit het feit dat deze producten geen fosfaatvrije voet kennen. Zeefgrond heeft, evenals compost, een hoge EOS/ $\mathrm{P}_{2} \mathrm{O}_{5}$-ratio; echter, omdat met zeefgrond relatief weinig OS per kg product wordt aangevoerd, draagt aanwending van zeefgrond in mindere mate bij aan het ophogen van het OS-gehalte van de ontvangende bodem.

Organische stof- en fosfaatgehalte

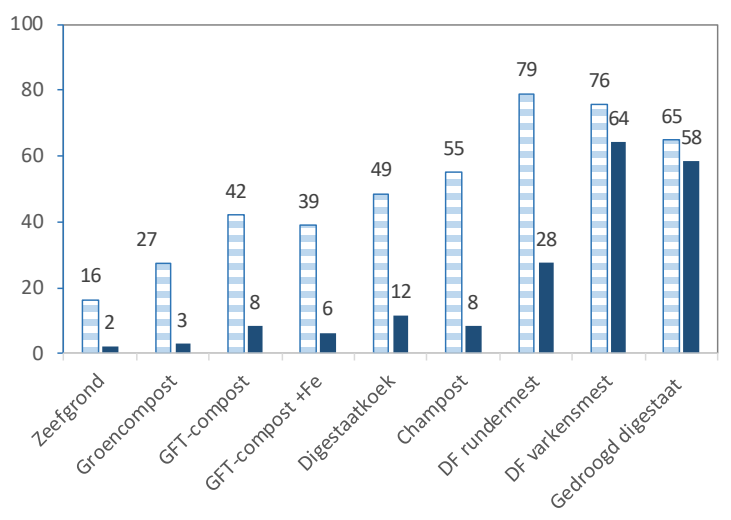

$\square$ Organische stof gehalte (\% d.s.) $\quad$ Fosfaat $\left(\mathrm{g} \mathrm{P}_{2} \mathrm{O}_{5} / \mathrm{kg}\right.$ d.s.)
Ratio EOS $/ \mathrm{P}_{2} \mathrm{O}_{5}$

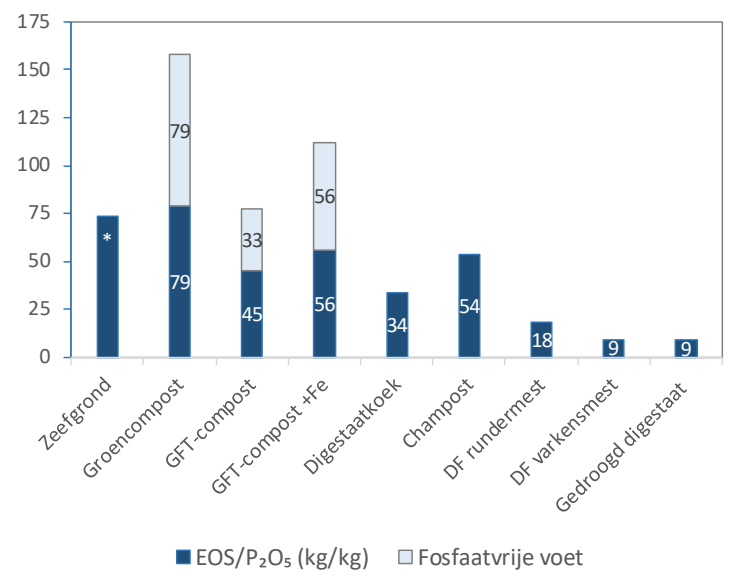

Figuur 1 Gemiddeld organischestofgehalte (\% van droge stof), fosfaatgehalte ( $\mathrm{g} \mathrm{P}_{2} \mathrm{O}_{5} / \mathrm{kg}$ drooggewicht) en de ratio tussen de effectieve organische stof (EOS) en het fosfaatgehalte ( $\mathrm{kg}$ EOS/ $\mathrm{kg}$ $\mathrm{P}_{2} \mathrm{O}_{5}$ ) in zeefgronden, composten, overige organische meststoffen en dierlijke mest. 
Tabel 3 Samenstelling van de zeefgronden, composten, overige organische meststoffen en producten van dierlijke mest, uitgedrukt op basis van de droge stof. Getallen tussen haakjes geven het percentage t.o.v. het totale fosfaatgehalte.

\begin{tabular}{|c|c|c|c|c|c|c|c|c|c|c|c|c|c|c|c|c|c|c|c|}
\hline & & DS $^{\mathrm{a}}$ & OS $^{\mathrm{a}}$ & $\mathrm{HC}^{\mathrm{a}}$ & pH & $\mathbf{P}_{2} \mathbf{O}_{5}$-tot & $\mathrm{EOS} / \mathrm{P}_{2} \mathrm{O}_{5}{ }^{\mathrm{a}}$ & N-tot & Fe-tot & S-tot & P-anorg ${ }^{b}$ & P-org ${ }^{b}$ & P-AL getal ${ }^{c}$ & $\mathrm{Fe}_{\mathrm{ox}}$ & $A l_{\text {ox }}$ & Pox & $\begin{array}{l}\text { P-verz. } \\
\text { graad d }^{\text {d }}\end{array}$ & $\begin{array}{c}\mathrm{P}-\mathrm{CaCl}_{2} \\
\mathrm{pH}- \\
\text { initieel }^{\mathrm{e}}\end{array}$ & $\begin{array}{l}\mathrm{P}-\mathrm{CaCl}_{2} \\
\mathrm{pH} 5,5^{\mathrm{e}}\end{array}$ \\
\hline & Product & $(\%)$ & $(\%)$ & $(\%)$ & $(-)$ & $(\mathrm{g} / \mathbf{k g})$ & $(\mathrm{kg} / \mathrm{kg})$ & $(\mathrm{g} / \mathrm{kg})$ & $(\mathrm{g} / \mathrm{kg}) \mid$ & $(\mathrm{g} / \mathrm{kg})$ & $\left(\mathrm{g} \mathrm{P}_{2} \mathrm{O}_{5} / \mathrm{kg}\right)$ & $\left(\mathrm{g} \mathrm{P}_{2} \mathrm{O}_{5} / \mathrm{kg}\right)$ & $\left(\mathrm{mg} \mathrm{P}_{2} \mathrm{O}_{5} / 100 \mathrm{gr}\right)$ & \multicolumn{3}{|c|}{$(\mathrm{mmol} / \mathrm{kg})$} & $(\mathrm{mol} / \mathrm{mol})$ & $\begin{array}{l}\text { (\% P- } \\
\text { tot) }\end{array}$ & $\begin{array}{c}\text { (\% P- } \\
\text { tot) }\end{array}$ \\
\hline 1 & Zeefgrond-1 & 70 & 21 & 95 & 6.9 & 2.9 & 67 & 7.0 & 6.3 & 1.1 & $2.2(85 \%)$ & $0.4(15 \%)$ & $149(51 \%)$ & 45 & 27 & $26(64 \%)$ & 0.37 & $0 \%$ & $6 \%$ \\
\hline 2 & Zeefgrond-2 & 75 & 11 & 95 & 6.8 & 1.9 & 56 & 3.6 & 5.1 & 0.6 & $1.2(77 \%)$ & $0.3(23 \%)$ & $80(43 \%)$ & 46 & 30 & $17(64 \%)$ & 0.22 & $0 \%$ & $0.8 \%$ \\
\hline 3 & Zeefgrond-3 & 66 & 18 & 95 & 6.7 & 1.7 & 97 & 3.9 & 4.5 & 0.5 & $1.1(75 \%)$ & $0.4(25 \%)$ & $54(31 \%)$ & 42 & 34 & $16(64 \%)$ & 0.21 & $0 \%$ & $1,0 \%$ \\
\hline 4 & Groencompost-1 & 42 & 39 & 90 & 7.9 & 3.5 & 99 & 7.9 & 10.1 & 1.1 & $2.4(77 \%)$ & $0.7(23 \%)$ & $174(49 \%)$ & 49 & 10 & $27(55 \%)$ & 0.46 & $1 \%$ & $13 \%$ \\
\hline 5 & Groencompost-2 & 67 & 16 & 90 & 7.0 & 2.5 & 59 & 6.0 & 8.6 & 1.5 & $1.7(76 \%)$ & $0.5(24 \%)$ & $110(45 \%)$ & 54 & 21 & $21(61 \%)$ & 0.28 & $0 \%$ & $2,0 \%$ \\
\hline 6 & Gft-compost-1 & 69 & 41 & 90 & 7.8 & 7.7 & 48 & 16.4 & 11.4 & 2.9 & $5.9(90 \%)$ & $0.7(10 \%)$ & $466(61 \%)$ & 36 & 13 & $68(62 \%)$ & 1.4 & $0 \%$ & $18 \%$ \\
\hline 7 & Gft-compost-2 & 69 & 43 & 90 & 7.6 & 9.2 & 42 & 15.2 & 5.0 & 6.6 & $6.9(90 \%)$ & $0.8(10 \%)$ & $588(64 \%)$ & 31 & 25 & $83(64 \%)$ & 1.5 & $5 \%$ & $22 \%$ \\
\hline 8 & Gft-compost $+\mathrm{Fe}-1$ & 60 & 35 & 90 & 8.0 & 6.9 & 45 & 14.3 & 7.3 & 2.1 & $5.3(92 \%)$ & $0.5(8 \%)$ & $445(65 \%)$ & 43 & 22 & $60(62 \%)$ & 0.92 & $1 \%$ & $22 \%$ \\
\hline 9 & Gft-compost $+\mathrm{Fe}-2$ & 67 & 44 & 90 & 7.5 & 5.9 & 67 & 18.3 & 11.1 & 2.6 & $5.9(81 \%)$ & $1.4(19 \%)$ & $445(76 \%)$ & 82 & 19 & $71(86 \%)$ & 0.70 & $1 \%$ & $15 \%$ \\
\hline 10 & Digestaatkoek & 33 & 49 & 80 & 8.4 & 11.7 & 34 & 25.9 & 19.9 & 9.8 & $7.6(78 \%)$ & $2.1(22 \%)$ & $440(38 \%)$ & 273 & 12 & $101(61 \%)$ & 0.35 & $1 \%$ & $14 \%$ \\
\hline 11 & Champost & 31 & 55 & 82 & 6.7 & 8.4 & 54 & 21.2 & 1.2 & 25.8 & $2.4(35 \%)$ & $4.4(65 \%)$ & $486(58 \%)$ & 14 & 5 & 82 (69\%) & 4.4 & $15 \%$ & $22 \%$ \\
\hline 12 & $\begin{array}{l}\text { Dikke fractie } \\
\text { rundermest }\end{array}$ & 26 & 79 & 64 & 7.1 & 27.6 & 18 & 24.9 & 2.6 & 7.5 & $20.7(93 \%)$ & $1.5(7 \%)$ & $>1000$ & 33 & 4 & $310(80 \%)$ & 8.6 & $8 \%$ & $45 \%$ \\
\hline 13 & $\begin{array}{l}\text { Dikke fractie } \\
\text { varkensmest }\end{array}$ & 31 & 76 & 80 & 8.7 & 64.2 & 9 & 38.0 & 2.8 & 6.5 & $48(99 \%)$ & $0.4(1 \%)$ & $>1000$ & 43 & 6 & $674(74 \%)$ & 13.7 & $2 \%$ & $87 \%$ \\
\hline 14 & $\begin{array}{l}\text { Gedroogd digestaat + } \\
\mathrm{Fe}\end{array}$ & 95 & 65 & 80 & 8.1 & 58.4 & 9 & 28.2 & 13.2 & 12.6 & $52.6(95 \%)$ & $2.7(5 \%)$ & $>1000$ & 172 & 18 & $653(79 \%)$ & 3.4 & $1 \%$ & $37 \%$ \\
\hline
\end{tabular}

a DS: droge stof; OS: organische stof; HC: humificatie-coëfficiënt (Rietra et al., niet gepubliceerd); EOS: effectieve organische stof.

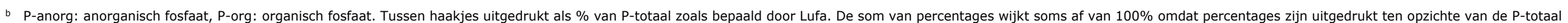
meting door Lufa.

c P-AL-getal: Fosfaatindicator voor landbouwgronden voor vaststelling van de fosfaatgebruiksnorm op grasland. P-Al-getal>50 wordt beoordeeld als 'hoog'.

d Feox, Alox en Pox: Fe, Al en P in zuur ammonium-oxalaat. Fosfaatverzadigingsgraad als maat voor de verzadiging van ijzer- en aluminiumoxiden met fosfaat, uitgedrukt als: Pox/0.5*(Feox+Alox).

e $\mathrm{P}$ - $\mathrm{CaCl}_{2}$ bij de initiële $\mathrm{pH}$ en na aanzuren tot $\mathrm{pH} 5,5$, uitgedrukt als $\%$ van P-totaal. 


\subsection{Fosfaatvormen en indicatoren voor fosfaatbeschikbaarheid}

\subsubsection{P-AL-getal}

In de landbouwpraktijk wordt het P-AL-getal gebruikt bij het opstellen van bemestingsadviezen en als indicator voor de fosfaattoestand op grasland en daarmee voor de hoogte van de fosfaatgebruiksnorm. Bij een P-AL getal > 55 wordt de bodemfosfaattoestand geclassificeerd als 'hoog'. Hogere P-AL-getallen komen veelvuldig voor in landbouwgronden; uit databestanden van Eurofins Agro blijkt dat het P-ALgetal in $25 \%$ van de aangeboden grondmonsters de waarde van $55 \mathrm{mg} \mathrm{P}_{2} \mathrm{O}_{5} / 100$ gram overschrijdt en in $5 \%$ van de aangeboden grondmonsters is het P-AL-getal hoger dan $100 \mathrm{mg} \mathrm{P}_{2} \mathrm{O}_{5} / 100$ gram (CDM, 2015). Een bovengrens is echter niet gegeven. In zeefgronden varieert het P-AL-getal tussen 54 en $149 \mathrm{mg} \mathrm{P}_{2} \mathrm{O}_{5} / 100$ gram en deze waarden vallen binnen het bereik van P-AL-getallen die voorkomen op landbouwgronden met een historie van hoge fosfaatgiften. Vergelijkbare P-AL-getallen werden gemeten in de twee groencomposten (110 en $174 \mathrm{mg} \mathrm{P}_{2} \mathrm{O}_{5} / 100 \mathrm{gram}$ ). De hoeveelheid fosfaat die met de $\mathrm{P}-\mathrm{AL}$ methode geëxtraheerd wordt uit zeefgronden en groencompost varieert tussen de 30 en $51 \%$ van totaalfosfaat en dit is vergelijkbaar met de fractie P-AL-extraheerbaar fosfaat in landbouwgronden (Ehlert et al., 2018). Aanzienlijk hogere waarden voor het P-AL-getal worden gerapporteerd voor gftcompost, champost, digestaatkoek en de dikke fracties van de co-vergiste mest ( $450 \mathrm{mg} \mathrm{P}_{2} \mathrm{O}_{5} / 100 \mathrm{~g}$ ) en deze waarden vallen ver buiten het bereik aan P-AL-getallen die voorkomen op landbouwgronden. Waarden voor het P-AL-getal boven 450 mg $\mathrm{P}_{2} \mathrm{O}_{5} / 100$ gram zijn door het uitvoerende laboratorium wel gerapporteerd; echter, in deze notitie zijn deze weergegeven als 'groter dan', omdat deze waarden ver buiten het normale bereik van de extractie- en meetmethode vallen waardoor artefacten kunnen ontstaan. Het gemiddelde P-AL-getal in zeefgrond en groencompost komt qua ordegrootte overeen met de 5\% landbouwgronden met de hoogste P-AL-getallen zoals aangeboden voor analyse bij Eurofins Agro. Zeefgrond en groencompost zijn daarmee op basis van het gemiddelde P-AL-getal niet onderscheidend van landbouwgronden met een geschiedenis van hoge fosfaatgiften, terwijl gft-compost en andere organische meststoffen wel onderscheidend zijn door een aanzienlijk hoger P-AL-getal. Tussen zeefgronden en composten zijn er aanzienlijke verschillen in de hoogte van het P-AL-getal waardoor een algemeen geldende conclusie op basis van de hier geanalyseerde aantallen producten niet te rechtvaardigen is.

\subsubsection{Organisch versus anorganisch fosfaat}

Fosfaat kan aanwezig zijn in de vorm van organisch fosfaat en anorganisch fosfaat. Anorganisch fosfaat $\left(\mathrm{PO}_{4}\right)$ kan door adsorptie binden aan minerale bodemdeeltjes en precipiteren met $\mathrm{Ca}$ en $\mathrm{Mg}$ tot calciumfosfaat en struviet. Anorganisch fosfaat is gewas-beschikbaar nadat het door desorptie of oplossen van fosfaatmineralen in oplossing is gekomen. Organisch fosfaat is gebonden in organische moleculen. Een veelvoorkomende vorm van organisch fosfaat is fytaat (inositol), wat voorkomt in graanvliesjes en zodoende ook in mest. Kippenmest en rundermest bevatten relatief veel organisch fosfaat. Organisch fosfaat dient eerst een mineralisatiestap te ondergaan tot anorganisch fosfaat voordat het gewas het fosfaat kan benutten.

In alle geteste gronden, composten en meststoffen is totaalfosfaat voor meer dan $75 \%$ aanwezig in minerale vorm en voor minder dan $25 \%$ in organische vorm. Een uitzondering hierop is champost, waarin circa $35 \%$ aanwezig was als mineraal fosfaat en circa $65 \%$ van totaalfosfaat in organische vorm. Er zijn wat onzekerheden over dit getal, omdat het hoge aandeel organisch P niet past bij het hoge aandeel van totaalfosfaat wat extraheerbaar is met P-AL (analyse als ortho-P). Deze discrepantie kan voortkomen uit het feit dat bepaalde organische fosfaatvormen onder zure condities makkelijk hydrolyseren tot anorganisch fosfaat, waardoor het onderscheid tussen beide vormen niet eenduidig is vast te stellen. De fractie organisch fosfaat is lager in dikke fracties van dierlijke mest in vergelijking met compost en zeefgronden. Tussen de composten en zeefgronden zit echter geen duidelijk verschil in de verdeling van fosfaat over anorganische en organische vorm en varieert het aandeel organisch fosfaat tussen 7 en $24 \%$. Ter vergelijking is in Tabel 4 het aandeel organisch fosfaat in bodemmonsters op grasland getoond, waaruit volgt dat in minerale gronden onder grasland circa 35\% van het fosfaat aanwezig is in organische vorm en in veengrond circa $72 \%$ van totaalfosfaat. Op 
bouwlandgronden zal dit aandeel lager zijn door een lager aandeel wortelbiomassa in de grond; echter, hierover zijn geen data voorhanden. Met correctie voor de verschillen in OS-gehalte tussen compost en de gronden in Tabel 4 (OS-gehalte 4 tot 10 keer hoger in composten) kan geconcludeerd worden dat de gehalten organisch $\mathrm{P}$ in composten $\left(0,5-1,4 \mathrm{~g} \mathrm{P}_{2} \mathrm{O}_{5} / \mathrm{kg}\right.$ d.s.) laag zijn ten opzichte van die in gronden onder grasland. Op basis daarvan wordt geen substantiële bijdrage vanuit mineralisatie van organisch $\mathrm{P}$ in composten verwacht. Dit past ook bij het verwerkingsproces dat compost heeft ondergaan, waarin het afbreekbare deel van de OS en organisch fosfaat reeds zijn afgebroken, en bij de hoge humificatie-coëfficiënt van compost.

Tabel $4 \quad$ Verdeling van fosfaat over anorganisch en organisch fosfaat in grondmonsters op grasland (0-30 cm diepte) bepaald met de $P$-kuo methodea. Tussen haakjes als \% van P-totaal.

\begin{tabular}{|c|c|c|c|c|}
\hline & $\begin{array}{l}\text { Organische stof } \\
(\%)\end{array}$ & $\begin{array}{l}\text { P-totaal } \\
\left(\mathrm{g} \mathrm{P}_{2} \mathrm{O}_{5} / \mathrm{kg}\right)\end{array}$ & $\begin{array}{l}\text { P-organisch } \\
\left(\mathrm{g} \mathrm{P}_{2} \mathrm{O}_{5} / \mathbf{k g}\right)\end{array}$ & $\begin{array}{l}\text { P-anorganisch } \\
\left(\mathrm{g} \mathrm{P}_{2} \mathrm{O}_{5} / \mathrm{kg}\right)\end{array}$ \\
\hline Zand & 3.9 & 1.51 & $0.56(37 \%)$ & $0.94(63 \%)$ \\
\hline Zand & 3.7 & 1.53 & $0.56(37 \%)$ & $0.97(63 \%)$ \\
\hline veen & 49.6 & 4.39 & $3.16(72 \%)$ & $1.23(28 \%)$ \\
\hline
\end{tabular}

a Bewerkt op basis van Ehlert et al. (2018). Analysemethode voor bepaling van organisch en anorganisch fosfaat is gelijk aan de methode gehanteerd voor de composten en meststoffen in onderhavige studie.

\subsubsection{IJzer-gebonden fosfaat}

Composten bestaan deels uit grond en fosfaat kan binden aan de ijzer- en aluminiumoxiden (hier afgekort tot ijzeroxiden) die van nature aanwezig zijn in de grondfractie. In bodems wordt de fosfaatbindingscapaciteit afgeleid aan de hand van de gehalten reactieve ijzer- en aluminiumoxiden in de bodem ( $\mathrm{Fe}_{\mathrm{ox}}$ en $\mathrm{Al}_{\mathrm{ox}}$ ), waarbij het gehalte $\mathrm{Fe}_{\mathrm{ox}}$ normaliter hoger is dan het gehalte $\mathrm{Al}_{\mathrm{ox}}$. Het totaalgehalte aan ijzer in grond of compost is geen goede maat voor het fosfaatbindend vermogen omdat een deel van ijzer gebonden is in kleimineralen en niet in staat is om fosfaat te binden. Naast $\mathrm{Fe}_{\mathrm{ox}}$ en $\mathrm{Al}_{\mathrm{ox}}$ wordt in hetzelfde extract fosfaat bepaald $\left(\mathrm{P}_{\mathrm{ox}}\right)$ als maat voor de hoeveelheid geadsorbeerd fosfaat. Het gehalte aan $\mathrm{P}_{\mathrm{ox}}$ is lager dan totaal- $\mathrm{P}$, omdat bijvoorbeeld organisch fosfaat en zeer stabiele fosfaatmineralen niet tot uiting komen in deze indicator. Gehalten aan $\mathrm{P}_{\mathrm{ox}}, \mathrm{Fe}_{\mathrm{ox}}$ en $\mathrm{Al}_{\text {ox }}$ worden uitgedrukt in $\mathrm{mmol} / \mathrm{kg}$, omdat de molaire verhouding tussen deze elementen bepalend is voor de mate van fosfaatverzadiging.

De fosfaatbindingscapaciteit is berekend met de volgende vergelijking:

$$
\text { Fosfaatbindingscapaciteit }=\left(0.5 * F e_{o x}+A l_{\text {ox }}\right) * 31 * 2.29
$$

De waarde 0,5 is een maat voor de maximale fosfaatbindingscapaciteit en als vuistregel wordt hiervoor de waarde 0,5 gebruikt (Van der Zee et al., 1987), al zijn er ook studies die pleiten voor een lagere waarde, omdat de hoeveelheid fosfaat die gebonden kan worden aan $\mathrm{Fe}_{\text {ox }}$ en $\mathrm{Al}_{\text {ox }}$ beïnvloed wordt door tal van factoren (Borggaard et al., 1990; Koopmans et al., 2004). Organische stof (met name humuszuren) adsorbeert, evenals fosfaat, aan ijzeroxiden, waardoor de maximale fosfaatbindingscapaciteit in theorie lager is bij een hoger OS-gehalte van de bodem, al zijn dergelijke effecten in praktijkmonsters vaak moeilijk aantoonbaar. De waarde 31 is de molaire massa van $P$ en de waarde 2.29 rekent $\mathrm{P}$ om tot $\mathrm{P}_{2} \mathrm{O}_{5}$, waardoor de eenheid van de fosfaatbindingscapaciteit $\mathrm{mg}$ $\mathrm{P}_{2} \mathrm{O}_{5} / \mathrm{kg}$ bodem wordt.

Het aandeel ijzer-gebonden fosfaat is vervolgens berekend als de ratio tussen de fosfaatbindingscapaciteit en het totaal fosfaatgehalte van het product. Voor zeefgrond, groencompost en digestaatkoek is het $\mathrm{P}_{\mathrm{ox}}$-gehalte lager dan de fosfaatbindingscapaciteit, wat wil zeggen dat ijzeroxiden niet volledig verzadigd zijn met fosfaat. Voor deze producten is de ratio $\mathrm{P}_{\mathrm{ox}} / \mathrm{P}$-totaal genomen als maat voor het aandeel ijzer-gebonden fosfaat. 
In zeefgrond en groencompost bedraagt het aandeel ijzer-gebonden fosfaat gemiddeld 64 en $58 \%$ van totaalfosfaat (Figuur 2). In de gft-compost van locaties zonder ijzerdosering is circa $22 \%$ van het fosfaat gebonden aan de ijzeroxiden en dit percentage neemt toe tot $46 \%$ voor gft-composten afkomstig van installaties met ijzerdosering. In champost en dikke fracties van dierlijke mest is nauwelijks fosfaat gebonden aan ijzer ( 3 tot $8 \%$ van totaalfosfaat). Dit percentage is iets hoger in het gedroogde digestaat afkomstig van een installatie waar ijzer wordt gedoseerd (12\% van totaalfosfaat). In digestaatkoek uit de suikerindustrie is fosfaat voor circa $61 \%$ gebonden aan ijzeroxiden, wat verklaard wordt door de dosering van ijzerzouten in het vergistingsproces waardoor de bindingscapaciteit voor fosfaat sterk wordt vergroot. Deze verschillen tussen de digestaten ontstaan door verschillen in de hoogte van het ijzergehalte ten opzichte van het totaal-fosfaatgehalte.

Het percentage ijzer-gebonden fosfaat is niet direct te linken aan grondgebonden fosfaat, omdat ook in grond niet alle fosfaat gebonden is aan ijzeroxiden. Een deel van het fosfaat is aanwezig in organische vorm of zeer stabiele mineralen. Het aandeel ijzer-gebonden fosfaat illustreert echter wel duidelijk de verschillen tussen zeefgronden en composten enerzijds en organische meststoffen uit dierlijke mest anderzijds. Het laat ook zien dat dosering van ijzer een grote invloed kan hebben op het aandeel ijzer-gebonden fosfaat.

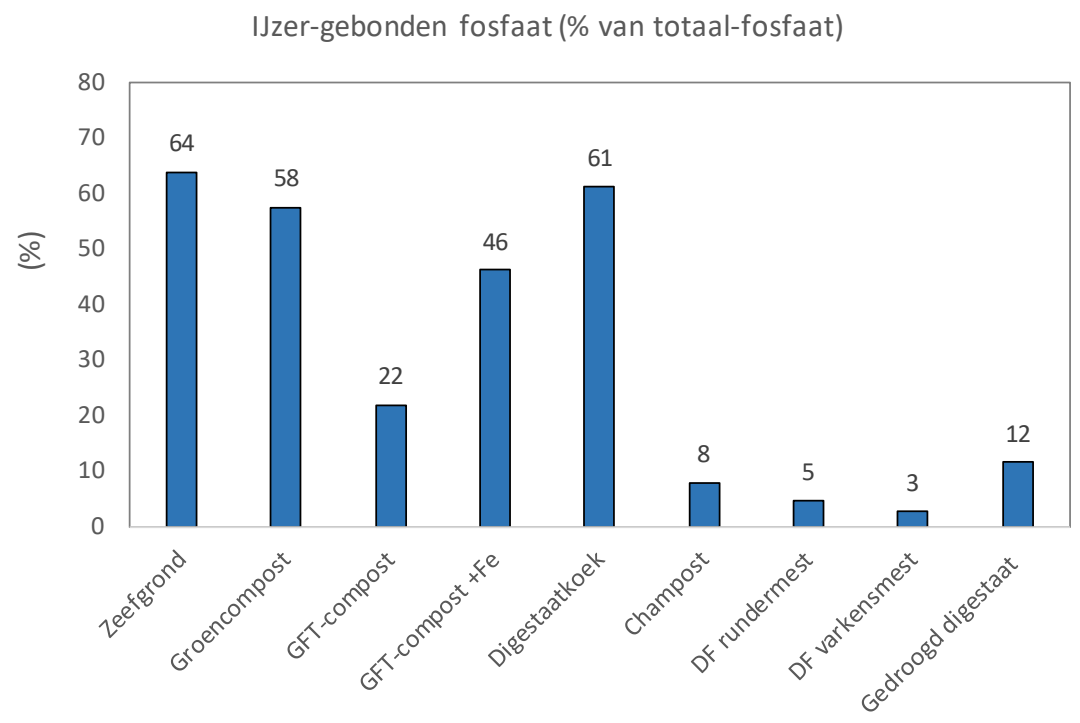

Figur 2 Gemiddeld aandeel fosfaat in zeefgrond, composten en meststoffen dat is gebonden aan ijzeroxiden (\% van totaal fosfaat), berekend op basis van het $P_{o x}{ }^{-}, F_{o x}-$ en $A_{\text {ox }}$-gehalte (voor berekening, zie tekst). Compost (Fe) is compost na vergisting en compostering en waarbij ijzerzouten worden gedoseerd tijdens de vergisting.

\subsubsection{Makkelijk beschikbare fosfaatfracties}

\section{Testen drie extractiemethoden}

Bij de bepaling van de beschikbare fosfaatconcentratie in grond is het gebruikelijk om dit te doen in een $10 \mathrm{mM} \mathrm{CaCl} 2$-oplossing bij de $\mathrm{pH}$ van de bodem te bepalen zodat de extractie een indicatie geeft van de fosfaatconcentratie in het bodemvocht. Bij composten en meststoffen geeft dit echter een vertekend beeld, omdat composten en meststoffen doorgaans een veel hogere $\mathrm{pH}$-waarde kennen dan de grond waarop het product wordt toegepast. Daarom is voor dit project de fosfaatconcentratie zowel bepaald bij de initiële $\mathrm{pH}$ als na aanzuren tot $\mathrm{pH}$ 5,5, wat overeenkomt met de gemiddelde $\mathrm{pH}$ op landbouwgronden op zand. Tevens is de inweeg van compost/meststof afgestemd op het fosfaatgehalte, zodat de producten vergeleken worden bij een vaste totaalfosfaatconcentratie in de suspensie om verschillen door precipitatie van fosfaatzouten te voorkomen. Als derde is de P-CATmethode uitgevoerd op de zeefgronden en composten. De P-CAT-methode is in Duitsland een standaardmethode voor analyse van macro- en micronutriënten in compost. De toevoeging van DTPA (een chelaat) zorgt voor een hogere extractie van micronutriënten en ijzer ten opzichte van enkel extractie met $\mathrm{CaCl}_{2}$. 
De volgende drie extractiemethoden zijn dus toegepast:

1. $\mathrm{P}-\mathrm{CaCl}_{2}$ : extractie met $10 \mathrm{mM} \mathrm{CaCl}_{2}$ en bij een inweeg van compost/meststof op basis van een vastgesteld totaal fosfaatgehalte in de suspensie (150 $\mathrm{mg} \mathrm{P/I}$ );

2. $\mathrm{P}-\mathrm{CaCl}_{2}-\mathrm{pH} 5,5$ : zoals 1 , maar na aanzuren met geconcentreerd $\mathrm{H}_{2} \mathrm{SO}_{4}$ tot $\mathrm{pH} 5,5$;

3. P-CAT methode: extractie met $10 \mathrm{mM} \mathrm{CaCl}_{2}$ en $2 \mathrm{mmol}$ DTPA.

Figuur 3 toont de verschillen in fosfaatconcentratie bepaald met de drie methoden voor zeefgrond, compost en de digestaatkoek. Bij de $\mathrm{P}-\mathrm{CaCl}_{2}$-methode is het aandeel beschikbaar fosfaat zeer laag en dit neemt fors toe na aanzuren van de $\mathrm{P}-\mathrm{CaCl}_{2}$-suspensie tot $\mathrm{pH} 5,5$. Bij de $\mathrm{P}-\mathrm{CaCl}_{2}-\mathrm{pH} 5,5$ methode is het aandeel beschikbaar fosfaat lager in zeefgrond en groencompost ten opzichte van de gft-compost en dit past bij de trends in de bovenbeschreven fosfaatindicatoren. Echter, de P-CAT-methode toont een tegengestelde trend waarbij het hoogste aandeel beschikbaar fosfaat wordt gevonden in zeefgronden en groencompost.

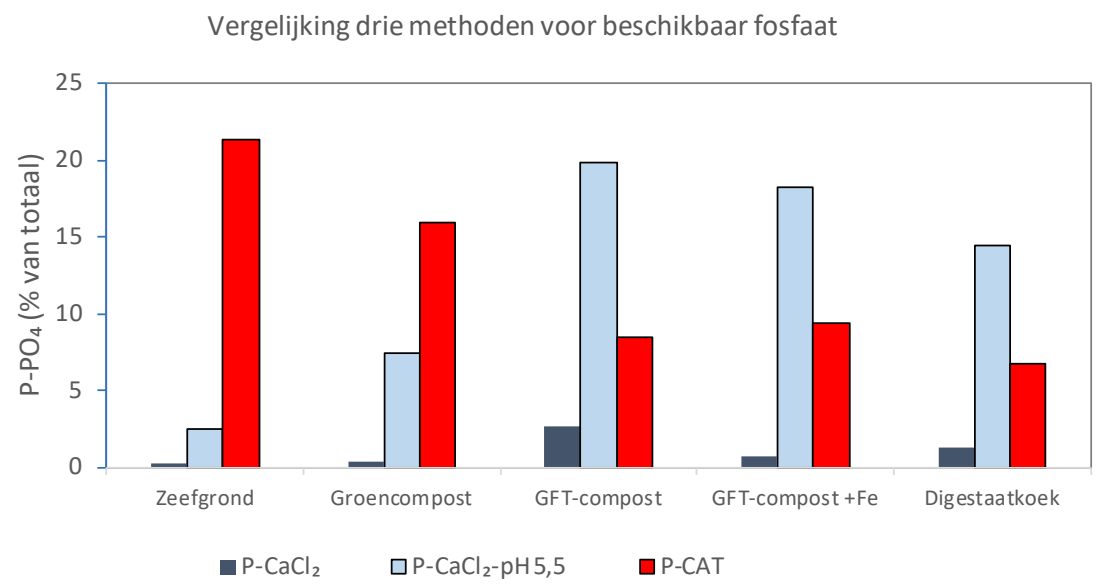

Figuur 3 Aandeel beschikbaar fosfaat (uitgedrukt als \% van totaal-fosfaat) na extractie met de $\mathrm{P}$-CaCl $\mathrm{C}_{2}$-methode, $\mathrm{P}$ - $\mathrm{CaCl}_{2}-\mathrm{pH}$,5-methode en de $\mathrm{P}$-CAT-methode.

Deze resultaten kunnen als volgt uitgelegd worden. Bij de $\mathrm{P}-\mathrm{CaCl}_{2}$-extractie wordt de fosfaatconcentratie in de oplossing gestuurd door de $\mathrm{pH}$ van de compost, die varieert tussen 7,0 en 8,0. Bij deze $\mathrm{pH}$ precipiteert fosfaat met calcium en magnesium, waardoor de gemeten fosfaatconcentratie in het extract bepaald wordt door het oplosbaarheidsproduct van deze fosfaatmineralen. Hierdoor lost maar een zeer klein deel van het fosfaat op. Door de suspensies aan te zuren naar $\mathrm{pH}$ 5,5 gaan calciumfosfaat en struviet in oplossing, terwijl fosfaatbinding aan ijzeroxiden in stand blijft. Hierdoor neemt de fosfaatconcentratie na aanzuren sterk toe bij de gft-compost en nauwelijks toe bij de zeefgronden ten opzichte van de niet-aangezuurde $\mathrm{P}-\mathrm{CaCl}_{2}-$ methode. $\mathrm{Bij} \mathrm{de}$ P-CAT-methode wordt daarnaast het chelaat DTPA toegevoegd, waardoor een deel van de ijzeroxiden én het daaraan gebonden fosfaat in oplossing gaat. De binding van Fe aan DTPA is sterk pHafhankelijk en neemt toe met een afnemende $\mathrm{pH}$. Dit versterkt het eerdergenoemde $\mathrm{pH}$-effect. In het CAT-extract zijn ook ijzerconcentraties gemeten (niet getoond) en deze nemen toe (van 2 tot 19\% van ijzertotaal) met een afnemende $\mathrm{pH}$ en correleren met het aandeel extraheerbaar fosfaat. De zeefgronden hebben een lagere $\mathrm{pH}(6,8)$ dan $\mathrm{gft}$-compost $(7,6-8,0)$ en daarom wordt meer ijzer en meer fosfaat geëxtraheerd uit de zeefgronden in vergelijking met de composten. De P-CAT-methode is daarom geen goede indicator voor de fosfaatbeschikbaarheid van composten en meststoffen. In de overige meststoffen is daarom alleen $\mathrm{P}-\mathrm{CaCl}_{2}$ met en zonder aanzuren bepaald.

\section{Makkelijk beschikbaar fosfaat in composten en meststoffen}

Figuur 4 toont het aandeel makkelijk beschikbaar fosfaat na extractie bij pH 5,5 voor de zeefgronden, composten en meststoffen. In zeefgrond en groencompost vallen 2 en $7 \%$ in de fractie makkelijk beschikbaar fosfaat, wat te relateren is aan de hoge mate van binding aan ijzer- en aluminiumoxiden in zowel zeefgrond als groencompost. Beschikbaar fosfaat bedraagt 20-25\% van P-totaal in de gftcomposten, omdat deze producten meer fosfaatprecipitaten bevatten (zoals struviet of 
calciumfosfaat), die bij pH 5,5 deels oplossen. Bij de meststoffen waar binding aan ijzeroxiden geen rol speelt (co-vergiste varkensmest en rundermest), is $45-87 \%$ van het fosfaat makkelijk beschikbaar. De fractie beschikbaar fosfaat is echter lager in het gedroogde digestaat, wat deels verklaard kan worden door de dosering van ijzer op deze installatie en daarnaast door een slechtere oplosbaarheid van de fosfaten na drogen. In champost en digestaatkoek is het aandeel makkelijk beschikbaar fosfaat laag, wat voor champost gerelateerd is aan het hoge aandeel organisch fosfaat en voor digestaatkoek verklaard kan worden door de dosering van ijzer.

Voor de dikke fractie van rundermest en varkensmest kunnen deze resultaten vergeleken worden met eerdere extracties met zure oplossingen die destijds zijn uitgevoerd om de perspectieven voor fosfaatverwijdering en terugwinning vast te stellen. Uit deze eerdere onderzoeken blijkt dat in aangezuurde dikke fractie van varkensmest (zowel vergist als niet-vergist) meer fosfaat in oplossing gaat (75-90\%) dan na aanzuren van rundermest (40-60\%) (Schoumans et al., 2017; Timmerman et al., 2018). Een hoger aandeel organisch fosfaat in rundermest (met name door fytaten) is een mogelijke verklaring, al wordt dat in deze studie niet bevestigd.



Figuur 4 Makkelijk beschikbaar fosfaat (\% van totaalfosfaat) bepaald als $\mathrm{P}_{-} \mathrm{PO}_{4}$ na extractie met $10 \mathrm{mM} \mathrm{CaCl}_{2}$ bij een $\mathrm{pH}$ van 5,5 en een schudverhouding afgestemd op het totaalfosfaatgehalte van de meststof.

\subsection{Fosfaatindicatoren in compost versus organischestofgehalte}

Het analyseren van de verschillende fosfaatvormen in composten is een tijdrovende zaak en zodoende is er vanuit de praktijk behoefte aan een eenvoudige indicator voor de fosfaatbeschikbaarheid. Het OS-gehalte wordt standaard bepaald in composten en de relaties tussen het OS-gehalte en een aantal fosfaatindicatoren zijn in Figuur 5 geplot. De figuren beperken zich tot data voor de composten en zeefgronden, omdat de organische meststoffen sterk afwijken van deze relaties door hun verschil in herkomst.

Het OS-gehalte in de composten en zeefgronden varieert tussen de 11 en $44 \%$ en is positief gecorreleerd met totaalfosfaat $\left(R^{2}: 0,71\right)$, het aandeel ijzer-gebonden fosfaat $\left(R^{2}: 0,45\right)$ en het aandeel makkelijk oplosbaar fosfaat $\left(R^{2}: 0,81\right)$. Het aantal monsters $(n: 9)$ is echter te beperkt om conclusies te trekken over de geschiktheid van OS als indicator voor de fosfaatbeschikbaarheid. Het OS-gehalte in de composten en zeefgronden is negatief gecorreleerd met het gehalte ijzer- en aluminiumoxiden, wat duidt op een hoger aandeel grond bij een lager OS-gehalte. Uitzondering hierop 
is echter één monster met een sterk verhoogd ijzergehalte door het gebruik van ijzerzouten tijdens de vergisting van gft-afval voor compostering. Omdat ijzerdosering tevens een effect heeft op de fosfaatverzadigingsgraad en het aandeel makkelijk beschikbaar fosfaat, mag verwacht worden dat het OS-gehalte geen goede indicator is voor de fosfaatvormen in composten afkomstig van installaties met ijzerdosering. Voor verwerkingsinstallaties zonder ijzerdosering kan het OS-gehalte dienen als een eenvoudige indicator voor de fosfaatvormen waarbij een hoger OS-gehalte overeenkomt met een hoger aandeel makkelijk beschikbaar fosfaat en een lager aandeel ijzer-gebonden fosfaat. De nauwkeurigheid van deze relaties moet verder onderbouwd worden met data van grotere aantallen composten.
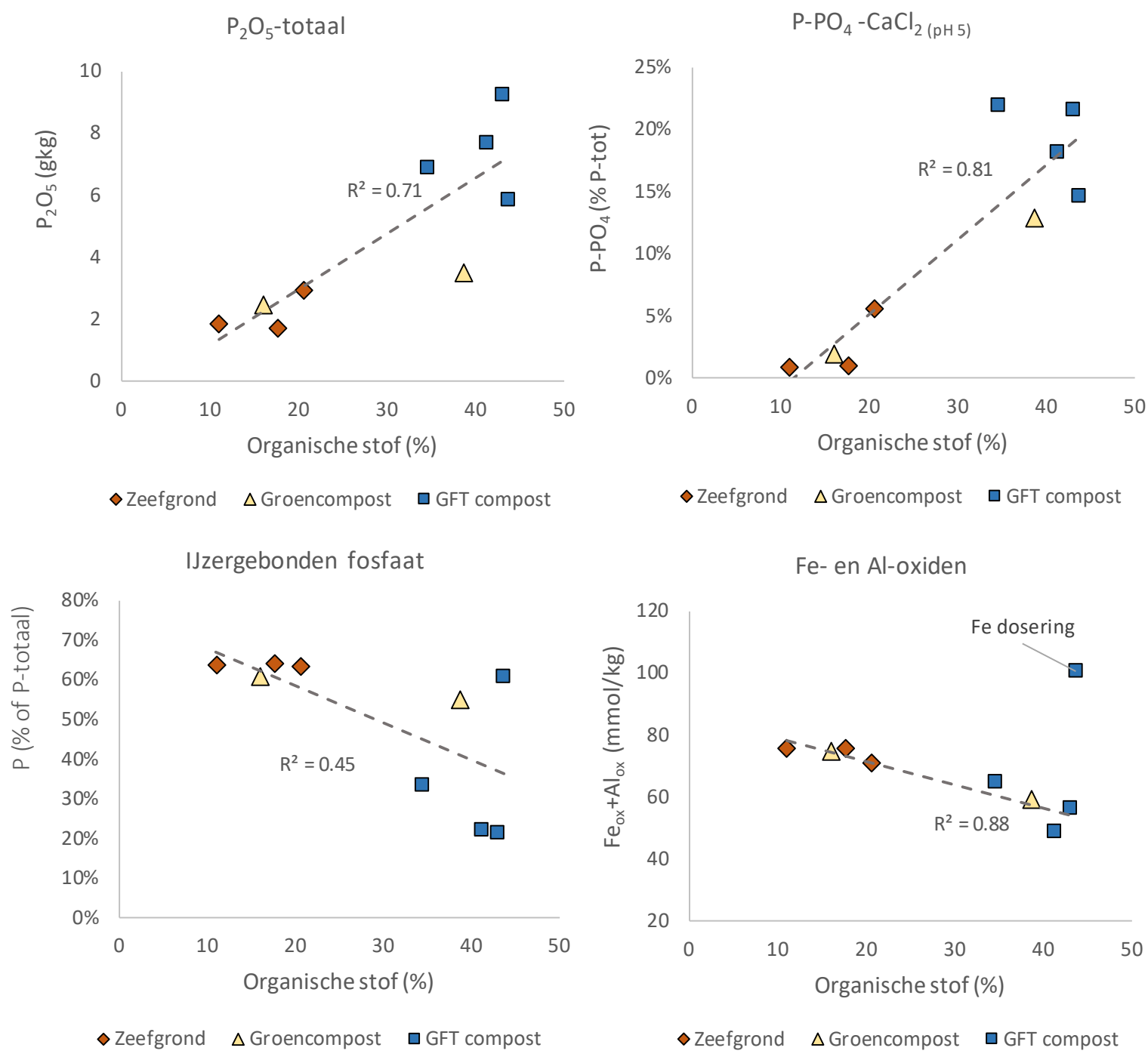

Figuur 5 Relaties tussen het organischestofgehalte in zeefgronden ( $n: 3)$, groencompost ( $n: 2)$ en gft-compost (n:3) versus totaalfosfaat (a), het percentage makkelijk beschikbaar fosfaat bepaald bij $\mathrm{pH}$ 5,5 (b), ijzer-gebonden fosfaat (c) en het gehalte aan ijzer- en aluminiumoxiden (d). 


\section{Synthese}

Groencompost en gft-composten zijn het eindproduct van verwerking van respectievelijk groenafval en bron-gescheiden groente-, fruit- en tuinafval. Door het gebruik van groenafval en tuinafval bestaat compost deels uit grond en dit heeft geleid tot de invoering van een fosfaatvrije voet voor compostproducten vanuit het principe van de basisvrachtbenadering. Immers, de aanvoer van grond en het daarbij behorende fosfaat kan niet gezien worden als bemesting van de bodem, maar valt onder hergebruik of verplaatsen van grond. Fosfaat in compost is zodoende voor $50 \%$ vrijgesteld van de fosfaatgebruiksnormen (tot een maximale vrijstelling van 3,5 g $\mathrm{P}_{2} \mathrm{O}_{5} / \mathrm{kg}$ droge stof). De hoogte van deze fosfaatvrije voet is eerder onderbouwd op basis van het aandeel grond in composten (Ehlert, 2005). Er is echter behoefte aan een bredere onderbouwing van deze vrijstelling. Tevens leidt de fosfaatvrije voet tot vragen over de mate waarin fosfaat beschikbaar is ten opzichte van andere organische meststoffen.

In deze studie zijn composten, zeefgrond, overige organische meststoffen en dikke fracties van covergiste dierlijke mest geanalyseerd op samenstelling, aanwezigheid van verschillende fosfaatvormen en indicatoren voor de fosfaatbeschikbaarheid. Er is onderscheid gemaakt tussen de volgende fosfaatvormen:

- Fosfaattoestand o.b.v. het P-AL-getal (fosfaatindicator op landbouwgronden);

- Verdeling over organische en anorganische vormen van fosfaat;

- Fosfaatbindingscapaciteit $\left(\mathrm{Fe}_{\mathrm{ox}}+\mathrm{Al}_{\mathrm{ox}}\right)$ en aandeel ijzer-gebonden fosfaat;

- Makkelijk beschikbaar fosfaat na extractie met $10 \mathrm{mM} \mathrm{CaCl} 2$ bij pH 5,5.

Ter vergelijking is bij de composten ook de Duitse P-CAT-methode gebruikt en de $\mathrm{CaCl}_{2}$-methode zonder aanpassing van de $\mathrm{pH}$.

Op basis van de diverse analyses is totaalfosfaat ingedeeld in drie categorieën (Figuur 6), namelijk:

- Makkelijk beschikbaar fosfaat (oplosbaar in $10 \mathrm{mM} \mathrm{CaCl} 2$ bij pH 5,5);

- IJzer-gebonden fosfaat (berekend; zie paragraaf 3.2.3);

- De restfractie bestaande uit organisch fosfaat en slecht oplosbare fosfaatmineralen.

Bij de interpretatie moet rekening gehouden worden met het feit dat het een verkennende studie betreft naar de mogelijkheden om fosfaatvormen in compost en organische meststoffen af te leiden op basis van een aantal fosfaatindicatoren. De studie is uitgevoerd op één tot vier monsters per productgroep, waardoor de variatie in de verdeling over de fosfaatvormen binnen productgroepen onbekend blijft en de dataset te beperkt is voor het trekken van algemeen geldende conclusies.

\section{Fosfaatvormen in compost en organische meststoffen}

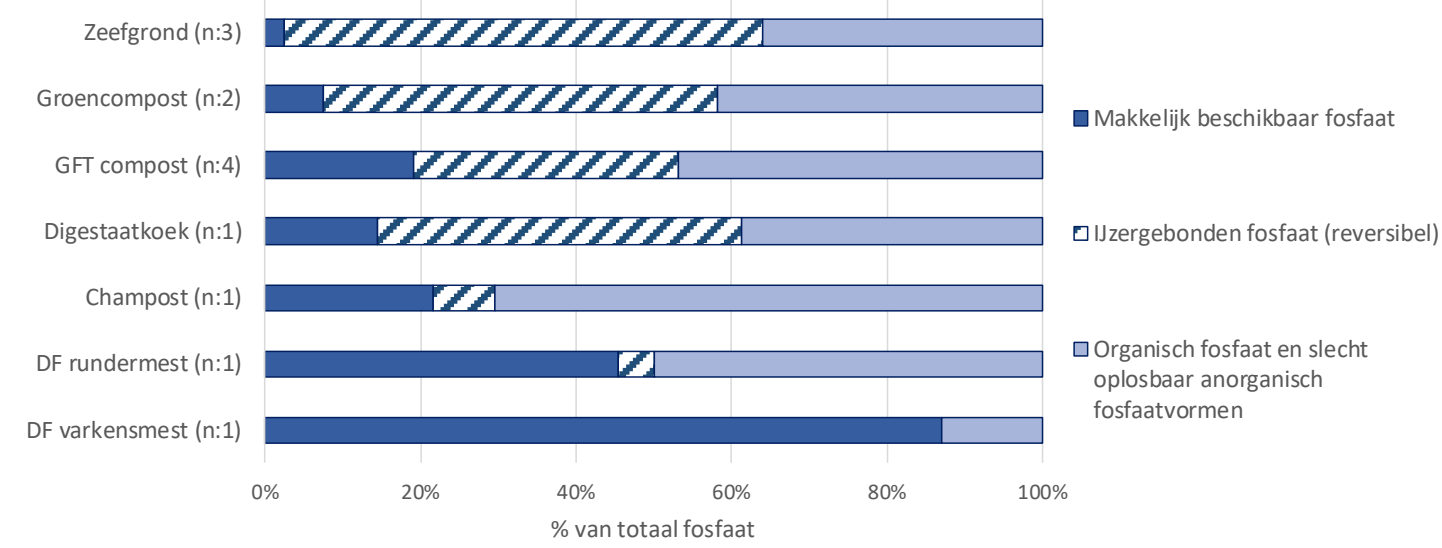

Figuur 6 Gemiddelde verdeling van fosfaat tussen (i) Makkelijk beschikbaar fosfaat (ii) fosfaat gebonden aan ijzer- en aluminiumoxiden (reversibel) en (iii) overige fosfaatvormen waaronder organisch fosfaat en slecht oplosbare fosfaatmineralen. 
Zeefgrond is op basis van de fosfaatindicatoren niet te onderscheiden van landbouwgronden met een hoge fosfaattoestand. Een groot deel van het fosfaat is gebonden aan ijzeroxiden of niet extraheerbaar met de $\mathrm{P}_{\text {ox }}$-extractiemethode. Ook in landbouwgronden is niet alle fosfaat gebonden aan ijzeroxiden, omdat een deel is vastgelegd in de vorm van organisch fosfaat of slecht oplosbare calciumfosfaten (Ehlert et al., 2018). De makkelijk beschikbare fosfaatfractie in zeefgronden bedraagt gemiddeld $2 \%$ van het totaalfosfaat, wat betekent dat fosfaat bij aanwending van zeefgrond op een lichtzure bodem nagenoeg volledig geassocieerd blijft met de zeefgrond. Door nalevering (i.e. desorptie van fosfaat) kan het fosfaat uit zeefgrond wel beschikbaar komen voor plantopname. Het aanwenden van zeefgrond leidt, in tegenstelling tot bemesting, niet tot een verhoging van het fosfaatgehalte in de ontvangende bodem, tenzij de ontvangende bodem een zeer lage fosfaatstatus kent.

De dikke fractie van rundermest en varkensmest bevat vrijwel geen fosfaat dat gebonden is aan ijzeroxiden. Het betreft hier monsters van verwerkingsinstallaties waar geen ijzer wordt gedoseerd. Bij de aanwending van dikke fractie van dierlijke mest wordt fosfaat aangevoerd in een vorm die deels (45-85\%) makkelijk vrijkomt bij toepassing op lichtzure bodems. De vrijgekomen fosfaat zal vervolgens adsorberen aan de ontvangende bodem en draagt zodoende bij aan het ophogen van de fosfaattoestand van de ontvangende bodem. In dikke fractie van co-vergiste rundermest is ongeveer de helft van het fosfaat aanwezig in de 'restfractie' en de fosfaatvormen in deze fractie zijn onzeker. Van rundermest is bekend dat een deel van het fosfaat aanwezig is als fytaat (Toor et al., 2005); echter, in deze studie bedroeg het aandeel organisch fosfaat slechts $7 \%$ van totaalfosfaat. Een kanttekening daarbij is dat het vaststellen van het aandeel organisch fosfaat een methode met onzekerheden is, omdat bepaalde fosfaatvormen tijdens de extractie met zuur kunnen hydrolyseren tot orthofosfaat, waardoor het organisch fosfaatgehalte wordt onderschat.

De gft-composten nemen op basis van de fosfaatindicatoren een middenpositie in tussen zeefgrond en dikke fracties van dierlijke mest. Gft-compost bevat beduidend meer beschikbaar fosfaat en heeft een hoger P-AL-getal dan verwacht mag worden voor landbouwgrond of zeefgrond. Het aandeel ijzergebonden fosfaat varieert tussen 22 en $61 \%$ en neemt toe met een hoger aandeel grond (lager OSgehalte) en is hoger wanneer op de verwerkingsinstallatie ijzerzouten worden gedoseerd om $\mathrm{H}_{2} \mathrm{~S}$ emissies in vergisters te beheersen. Groencompost toont in termen van fosfaatindicatoren sterke overeenkomsten met zeefgrond en onderscheidt zich van gft-compost door een lager aandeel makkelijk beschikbaar fosfaat en een hoger aandeel ijzer-gebonden fosfaat. Binnen de composten is er echter een grote spreiding in de verdeling over fosfaatvormen, mede door de grote verschillen in OSgehalte, en hierdoor zijn deze bevindingen niet generiek toe te passen op productgroepen.

Naast composten en dierlijke mest zijn tevens champost, digestaatkoek van reststromen uit de suikerbietenindustrie en gedroogd digestaat van een co-vergistingsinstallatie beoordeeld. In de twee digestaten werd eveneens een substantieel aandeel ijzergebonden fosfaat aangetroffen. In digestaatkoek is een groot deel van het fosfaat gebonden aan ijzer door het gebruik van ijzerzouten in het vergistingsproces en mogelijk ook door de aanwezigheid van tarragrond in de bietenpuntjes. In champost kan het hoge aandeel organisch fosfaat een verklaring zijn voor de lagere directe beschikbaarheid. De analyses voor champost met betrekking tot organisch fosfaat en anorganisch fosfaat zijn echter niet consistent met de P-AL-analyse, welke hoger is dan het aandeel anorganisch fosfaat. Een heranalyse is gewenst om uitsluitsel te geven over het aandeel organisch fosfaat. In het gedroogde digestaat is eveneens een deel van het fosfaat gebonden aan ijzer (door dosering ijzerzouten), al kan dit alleen niet het lage aandeel beschikbaar fosfaat verklaren.

Met de gekozen fosfaatindicatoren is het goed mogelijk om verschillen in de verdeling van fosfaat over fosfaatvormen tussen composten en meststoffen vast te stellen. Groencompost en gft-compost zijn daarbij duidelijk te onderscheiden van dikke fracties uit dierlijke mest van installaties zonder ijzerdosering. Met de methode is te onderbouwen dat een deel van het fosfaat in groencompost en gftcompost gebonden is aan ijzeroxiden, wat leidt tot een lager aandeel makkelijk beschikbaar fosfaat. Dit ondersteunt de toegepaste fosfaatvrije voet voor compostproducten. Voor groencompost zou een hogere vrijstelling te rechtvaardigen zijn, aangezien groencompost op basis van de fosfaatindicatoren niet duidelijk is te onderscheiden van zeefgrond. Er zijn echter slechts twee groencomposten geanalyseerd. Het aandeel ijzer-gebonden fosfaat laat zich niet een-op-een vertalen naar het aandeel 
fosfaat afkomstig uit de grondfractie, omdat in landbouwgronden fosfaat ook verdeeld is over diverse vormen, waaronder ijzer-gebonden fosfaat, organisch fosfaat en slecht oplosbare calciumfosfaten. Het aandeel grondgebonden fosfaat kan daardoor hoger zijn dan het aandeel ijzer-gebonden fosfaat. Anderzijds kan het aandeel ijzer-gebonden fosfaat in gft-compost deels beïnvloed zijn door de dosering van ijzerzouten tijdens het verwerkingsproces. Het onderscheid tussen gft-compost en andere meststoffen is minder duidelijk bij meststoffen afkomstig van installaties waar ijzerzouten worden gedoseerd omdat dit - evenals de aanwezigheid van grond - leidt tot een lager aandeel makkelijk beschikbaar fosfaat. Daarnaast is er tussen meststoffen (niet zijnde compost) ook een grote variatie in de verdeling van fosfaat over fosfaatvormen.

Het analyseren van de verschillende fosfaatvormen in composten is kostbaar en zodoende is er behoefte aan een eenvoudige indicator, zoals het OS-gehalte voor de fosfaatbeschikbaarheid. Een hoger OS-gehalte correspondeert met een lager gehalte aan ijzer- en aluminiumoxiden door een lager aandeel grond en daardoor een hogere fosfaatbeschikbaarheid. Deze relaties gaan echter niet op indien het ijzergehalte verhoogd is door dosering van ijzerzouten gedurende het verwerkingsproces, omdat de binding van fosfaat aan ijzer effecten heeft op de beschikbare fosfaatfractie. 


\section{$5 \quad$ Conclusie}

$\mathrm{Er}$ is een verkennende studie uitgevoerd naar de verdeling van fosfaat over verschillende fosfaatvormen in zeefgrond, groencompost, gft-compost, dikke fracties dierlijke mest, champost en digestaatkoek.

- Op basis van het P-AL-getal zijn zeefgrond en groencompost niet onderscheidend van landbouwgronden, terwijl gft-compost en andere organische meststoffen wel onderscheidend zijn door een hoger P-AL-getal.

- Het aandeel organisch fosfaat in compost is laag en vergelijkbaar met wat verwacht mag worden in grond. Op basis daarvan wordt geen substantiële bijdrage vanuit mineralisatie van organisch $\mathrm{P}$ in composten verwacht. Dit past ook bij het verwerkingsproces dat compost heeft ondergaan en waarin het afbreekbare deel van de OS en organisch fosfaat reeds is afgebroken en bij de hoge humificatiecoëfficiënt van compost.

- Op basis van de gehalten aan ijzer- en aluminiumoxiden is het aandeel ijzer-gebonden fosfaat bepaald. In zeefgrond $(n: 3)$ en groencompost $(n: 2)$ is circa $60 \%$ van het fosfaat gebonden aan ijzeroxiden. In gft-compost is er een grote spreiding in het aandeel ijzer-gebonden fosfaat (22-66\% van totaal fosfaat) door verschillen in het aandeel grond en het wel/niet doseren van ijzerzouten tijdens de verwerking. Het aandeel ijzer-gebonden fosfaat is hoger dan in dikke fracties van dierlijke mest, maar niet duidelijk afwijkend van digestaatkoek uit de suikerindustrie.

- Het aandeel makkelijk beschikbaar fosfaat (oplosbaar bij pH 5,5 in $10 \mathrm{mM} \mathrm{CaCl}$ ) neemt toe in de volgorde zeefgrond, groencompost, gft-compost/champost/digestaatkoek en dierlijke mest.

- De bemestende werking van groencompost en gft-compost verschilt van dierlijke mest. Fosfaat gebonden aan de grondfractie kan door nalevering beschikbaar komen voor gewasopname en draagt daarmee bij aan de totale fosfaatvoorraad per hectare, maar grondgebonden fosfaat draagt niet of zeer beperkt bij aan het ophogen van de fosfaattoestand van de ontvangende bodem. 


\section{Literatuur}

Borggaard, O.K., 1990. Influence of organic matter on phosphate adsorption by aluminium and iron oxides in sandy soils. J. Soil Sci. 41, 443-449. https://doi.org/10.1111/j.13652389.1990.tb00078.x

Ehlert, P.A.I., 2005. Toepassing van de basisvrachtbenadering op fosfaat van compost : advies. Rapp. / Wettelijke Onderz. Nat. Milieu;5.

Koopmans, G.F., Chardon, W.J., Ehlert, P.A.I., Dolfing, J., Suurs, R.A.A., Oenema, O., van Riemsdijk, W.H., 2004. Phosphorus Availability for Plant Uptake in a Phosphorus-Enriched Noncalcareous Sandy Soil. J. Environ. Qual. 33, 965. https://doi.org/10.2134/jeq2004.0965

Schoumans, O.F., Ehlert, P.A.I., Regelink, I.C., Nelemans, J.A., Noij, I.G.A.M., van Tintelen, W., Rulkens, W.H., 2017. Chemical phosphorus recovery from animal manure and digestate. https://doi.org/10.18174/426297

Timmerman, M., Regelink, I.C., Verdoes, N., Kuipers, G., Blanken, K., 2018. Fosfaatvormen in melkveemest en potentieel voor terugwinning 1087.

Toor, G.S., Cade-Menun, B.J., Sims, J.T., 2005. Establishing a linkage between phosphorus forms in dairy diets, feces, and manures. J. Environ. Qual. 34, 1380-1391.

https://doi.org/10.2134/jeq2004.0232 
Wageningen Environmental Research Postbus 47

6700 AA Wageningen

T 0317480700

www.wur.nl/environmental-research

Wageningen Environmental Research Rapport 3067

ISSN 1566-7197
De missie van Wageningen University \& Research is 'To explore the potential of nature to improve the quality of life'. Binnen Wageningen University \& Research bundelen Wageningen University en gespecialiseerde onderzoeksinstituten van Stichting Wageningen Research hun krachten om bij te dragen aan de oplossing van belangrijke vragen in het domein van gezonde voeding en leefomgeving. Met ongeveer 30 vestigingen, 6.500 medewerkers ( $5.500 \mathrm{fte}$ ) en 12.500 studenten behoort Wageningen University \& Research wereldwijd tot de aansprekende kennisinstellingen binnen haar domein. De integrale benadering van de vraagstukken en de samenwerking tussen verschillende disciplines vormen het hart van de unieke Wageningen aanpak. 


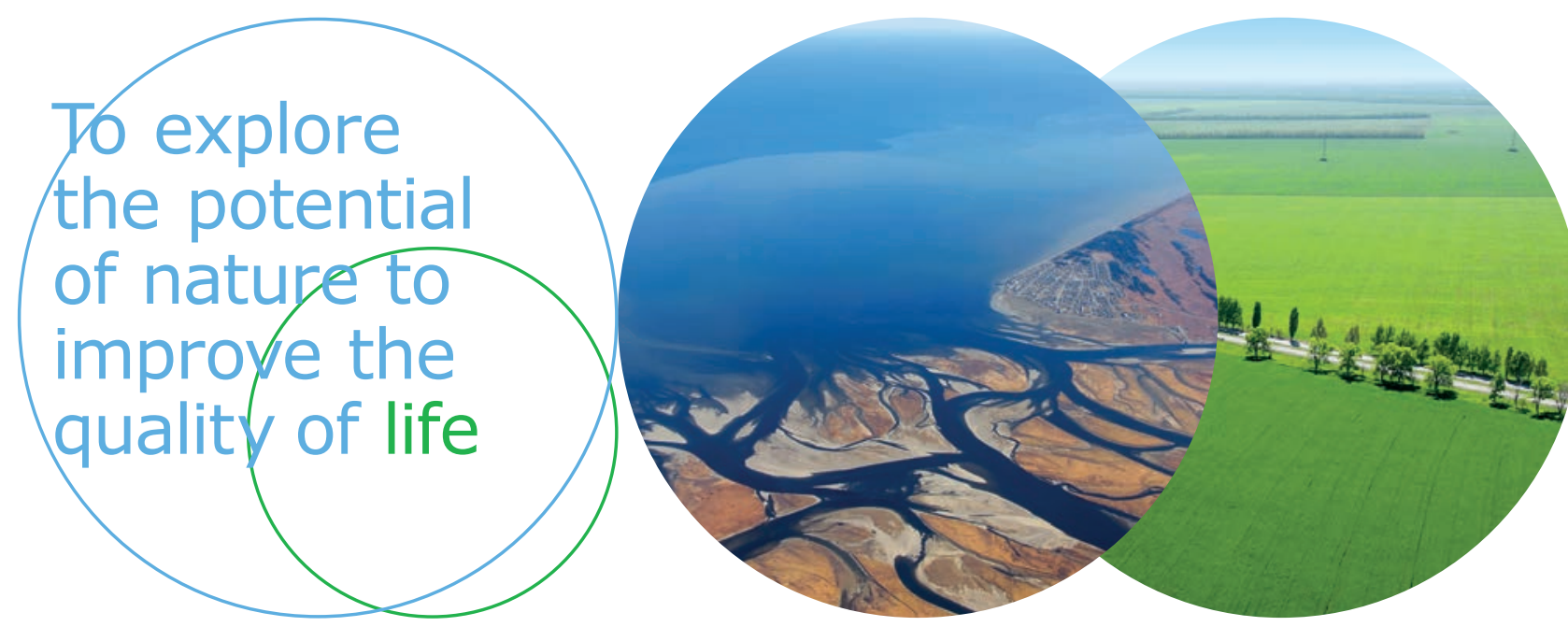

Wageningen Environmental Research Postbus 47

$6700 \mathrm{AB}$ Wageningen

T 317480700

www.wur.nl/environmental-research

Rapport 3067

ISSN 1566-7197
De missie van Wageningen University \& Research is 'To explore the potential of nature to improve the quality of life'. Binnen Wageningen University \& Research bundelen Wageningen University en gespecialiseerde onderzoeksinstituten van Stichting Wageningen Research hun krachten om bij te dragen aan de oplossing van belangrijke vragen in het domein van gezonde voeding en leefomgeving. Met ongeveer 30 vestigingen, 6.500 medewerkers ( $5.000 \mathrm{fte}$ ) en 12.500 studenten behoort Wageningen University \& Research wereldwijd tot de aansprekende kennisinstellingen binnen haar domein. De integrale benadering van de vraagstukken en de samenwerking tussen verschillende disciplines vormen het hart van de unieke Wageningen aanpak. 